\title{
Development of the university education in the context of globalization
}

\author{
Mikhail V. Boguslavskii ${ }^{1, *}$, Yegor V. Neborskii ${ }^{2}$ \\ ${ }^{1}$ ISED RAE, Laboratory of History of Pedagogy and Education, 105062, Moscow, Russia \\ ${ }^{2}$ USU, Department of Pedagogy and Pedagogical Psychology, Izhevsk, Russia
}

\begin{abstract}
The article focuses on the development of university education in the context of globalization processes. The modern concept of the University has changed considerably. The processes of globalization and transition to the knowledge economy are transforming the architectonics of the University and university education. Education is becoming increasingly international with constantly growing number of foreign students. The modern university is undergoing serious transformations: its qualitative characteristics are changing, the transition is occurring from the classical university to the innovative university, from the classical higher education paradigm to the postclassical. New forms of higher education are being developed: open university, network university, multiversity, educational hub and E-learning.
\end{abstract}

\section{Introduction}

In the modern world, universities, as well as the whole higher education system, are going through hard times. The University has to struggle to maintain its role as a unique cultural and scientific centre propagating advanced ideas.

As far back as the end of the twentieth century, many scientists and researchers declared about the University death [1], or its destruction and existence in ruins [2]. Logically, this would have to mean the end of higher education itself. However it still exists and fulfills rather important social functions: from transmission of cultural ideas and values to reproduction of economically useful knowledge. Toplevel universities included into different international ratings such as THE, QS or ARWU, continue to extend the sphere of their political influence, against seemingly dismal outlook. According to UNESCO statistics, the number of tertiary students enrolled in world universities has been gradually increasing. The proportion of international students as a percentage of total enrolments accounts for $19 \%$ in the USA, followed by the UK (10\%), Australia (6\%), France $(6 \%)$, Germany $(5 \%)$, Canada (3\%), Japan (3\%), Russia (3\%), China (2\%), Italy (2\%) [3], contrary to the prevailing belief that the share of foreign and internationally "mobile" students remains about the same in relation to national students. The reality is changing.

Perhaps, the University is still alive? Perhaps, higher education as an organizational form of the teaching-learning process will be as popular as before? One thing is evident: the system of higher education is undergoing serious transformations. This concerns education as a whole, the principles of its organization, and pedagogical professions. Traditional forms of instruction [5, 6], "the classroom" [7] are being rethought; new approaches to the organization of the teaching and learning are being worked out: MOOCs, storytelling, dynamic evaluation, etc. [8]. Seamless transition is occurring from the classical to the postclassical higher education paradigm [9]: the new educational reality is being constructed, where teacher's and student's roles radically change as well as the principles and goals of the educational process [10].

The University and higher education maintain themselves as a complex social phenomenon. However, changes in the environment and conditions of existence of the given object lead to changes in its content. What are the prospects for the University and higher education? In what context do they exist? How are they influenced by the globalization process? These are the issues to be examined in the article.

\section{The knowledge economy, globalization and higher education: the new context}

In some experts' opinion, the modern educational system has exhausted itself. It began to emerge with industrialization, at the Age of the Enlightenment, so the necessity to change the view of its outmoded principles has become quite evident [11]. The classical university represented a cultural center [12], where students absorbed intellectual tradition [13] and acquired life guiding principles and world perception

\footnotetext{
Corresponding author: hist2001@mail.ru
} 
rather than professional skills [14]. With time, the idea of the classical university, in Europe in particular, was enriched by such element as a scientific learning process; universal knowledge was narrowed to scientific knowledge [15]. It was so called Humboldtian model, which served as the University's foundation and ideological construct.

Firstly, the industrial economy based on Marx's classical theory is being transformed into the knowledge economy. Humankind has experienced the information revolution, the so-called "third wave" which has altered the organizational principles of economies and societies [16]. Tacit knowledge, which may be impossible to codify, has become important and is a key competitive differentiator in the new innovation economy [17]. While scientific knowledge presents new facts about something which has already existed in nature, tacit knowledge [18] involves creative activity which results in a new material object such as a computer, a telephone, a car, etc. [19]. The cognitive capital becomes a key factor of production in contemporary economies [20]; knowledge is no longer perceived as a maxim, being replaced by the concept of Useful Knowledge.

Secondly, the information revolution and the development of the knowledge economy in the person of multinationals encouraged establishing translational social networks which shape a new type of social reality. Here we come to the globalization process. In the scientific community, the question of whether globalization is a social process, or a new element of the political discourse, or a mixture of both is still open to debate [21]. This is further complicated by the ongoing political processes. On the other hand, unquestioned is the fact the scientific and technological advance have reshaped the modern world. The shift occurred from the "Gutenberg Galaxy" to the "McLuhan Galaxy": the transition from the printing press to electronic mass media has compressed the entire world to the size of a village, so called "Global Village" [22]. Two educational spaces are developing in parallel: national and supranational [23]. The language of science is becoming universal; high mobility of young people through participation in exchange programs and free-lance is something that the University accepts as a social reality. Education as a process and an outcome steps over the boundaries of a nation-state and ethnic culture. Multicultural instruction emerges [24], when Academe and students begin to think in two-level terms, which results in dissinchronization of identity, multiplicity of cultural realia [25], "duplication of cultures"[26]. Globalization becomes a trigger for transformations in social, economic, political and cultural spheres of a society [27]. The processes occurring in the format of economic globalization are objectively extrapolated to the higher education system. Trade liberalization promotes the globalizing of education, which means that education, in its turn, is becoming transnational; universities adopt business methods and try to increase their share in the world higher education market.
The modern university acquires qualitatively new characteristics [28]. The ranking criteria are as follows: international education program; global curriculum; exterritorial teaching staff; virtual department; international education standards; international attestation and accreditation; international certification; international student and teacher mobility; international language of instruction [29].

Globalization enhances competition, forcing universities to struggle for world rating position. Boundaries become 'blurred', the education products are accessible to all students regardless of the locality through the proliferation of learning resource centers, preparation courses, MOOCs, etc. Traditional state attributes, such as reproduction of labor power, are increasingly losing their nation-state character [30]. Businesslike approach pushes universities towards academic capitalism with self-repayment as the main goal [31]. Many researchers believe that the privatization of higher education undermines its moral principles and distorts its mission [32], confining it to the selling of diplomas [33].

In such conditions the idea of the classical university is hardly suitable. There have been attempts to save it: if the classical science can no longer serve as an ideological anchor, then communicative forms of scientific and academic argumentation will act as an integrating factor [34] and will bring together all the various functions of the university teaching-learning process [35]. Based on Bakhtin's dialogism, the University was to become the forum for debate where teacher and student choose cooperative relationship in acquiring new knowledge [36]. Socratic maieutics presupposes harmony between the teacher and the student: the teacher leads the student to the sought-for conclusion. While De Saussure's communication implies transmission of the message from the sender to the recipient, which reminds the exchange of monologues, Bakhtin's dialogism asserts that people perceive information by means of inner understanding; word meanings change from ideolect to ideolect, from utterance to utterance; a living word contacts another living word [37]. The fight starts for the student's subjectness, for destruction of what school has done to $\operatorname{him}[38]$.

Philosophical reflections on the development of the university idea were confined to the traditional framework of the classical methodology. In their noble opposition to the administrative, technological university, philosophers overlooked the fact that the University emerged in the times of the Industrial Revolution and cannot develop according to the laws of the "factory of knowledge" at the period of the "third wave". As far as Bakhtin's dialogism and the teaching scene concept are concerned, they are still among the most resourceful in the philosophical search. The knowledge economy and information society require a different approach. From now on the student becomes a creator, while the teacher acts as a 
tutor, which brings us back to pure pedagogy devoid of Komenskii's educational technology. Up front is the tacit knowledge implying creativity, rather than the classical science describing objective reality. The University and higher education system evolve from the memory school to the thinking school [39]. Environment conditions, shaped by globalization and knowledge economy, transform the functions and the content of the University. Its external referent now is the process of creating products of cultural, social or economic value.

The transformed context requires redesigning all the processes occurring within the University. Thus, when we speak about the end of University, we mean the end of the Classical University and the transition to the Innovative University [40]. The University is dead long live the University!

\section{The new forms and resources of university education}

The development of modern technologies is gradually changing the architectonics of higher education. As surveys show, the university community in the person of students, Academe and administrators are expecting the teaching-learning process to become virtual and distant [41]. This is not about the total disappearance of the University which has always been of continued importance [42]. Rather, this means serious transformations in its form. There must be someone to develop educational programs and serve as a connecting link between students, science, business and industry. The University has also proved itself as a center of cultural reproduction [43], which is directly related to creativity and cannot be replaced by computers. Nation-states seek to control, or influence universities and higher education system which are seen as tools for transmitting social norms and values and a buffer between generations [44].

One of such new forms is the Open University, whose mission is to provide accessible distance learning. A number of countries already have such universities: Open University in the UK, Open University of the Netherlands, Open University of Israel, Sukhothai Thammathirat Open University in Thailand. However, distance learning may have other forms. Many universities in the USA and Europe design so called MOOCs (Massive Open Online Courses); Massachusetts Institute of Technology, Stanford and Harvard Universities persistently develop free LMS (Learning Management System) platforms for eLearning [45].

The process is going on. Thus, six universities have developed the joint system of credits which may be received at MOOCs delivered by these universities [46]. They are: Delft University of Technology in the Netherlands, Swiss Federal Institute of Technology in Lausanne (EPFL), Australian National University and the University of Queensland, the University of British Columbia in Canada, Boston University (the USA).
The next new form is the Network University, which comes from the eastern part of the world and represents an association of individual universities from different countries [47, 48]. They provide a common academic program based on the concept of a cultural educational paradigm [49]. In particular, these are the Network University of SCO (Shanghai Cooperation Organization) and the Network University of BRICS (Brazil, Russia, India, China and South Africa), which were created by analogy with the Bologna Process and remind a multiversity. The strengthening of the educational bloc of BRICS is evident here [50].

Multiversity [51] is one of the organizational forms of university education and university life in general [52]. Such university grows into numerous campuses, many of which become separate educational institutions. Multiversity is a multicenter and multifunctional higher education institution which provides different levels and conditions, for example, elite, mass, nonprofessional and professional, etc.

Education hub (or education bundle) is another form of university education. It is a kind of Knowledge Village or Education City where academic programs of different universities of the world are presented. Here among the leaders are Qatar, United Arab Emirates, Singapore, Malaysia, Hong Kong and Botswana [53].

Educational resources or online resources which have their space in the network and open access [54], such as Coursera, Academic Earth, edX, iversity and others, are treated by some experts as competitive or alternative organizational forms of higher education [55]. Most probably, such forms will further develop due to open access, the providing of a valid certificate after completing the course, etc. It should be noted, however, that universities actively employ and co-opt these resources. For example, the edX learning platform was founded by Harvard and The Massachusetts Institute of Technology [56]. So, it is too soon to speak about the university education being completely replaced by online courses. Rather, the question is about the evident global expansion of the leading universities from the world top 20 in the global university rankings. This state of things will be further aggravated by the globalization processes.

\section{Conclusion}

The University will survive and develop, at least in the nearest decades. Its form will surely change. The globalization processes, progression and transition to the knowledge economy are already inciting its serious transformations. The Classical University is dead, being replaced by new organizational forms of higher education: open university, network university, multiversity, educational hub. The Innovative University, as a new phase of evolution, offers various options.

The "third wave", the transition to the knowledge economy, the development of information technologies - all this necessitates restructuring university education 
processes. MOOCs and other E-learning resources will be further developed along with the so-called "Edutainment": the broad use of competent storytelling, cloud packages, animated lectures, 3-D simulators, information technologies, computer games and so on [57]. The instruction will be practiced in "mixed groups", the classical forms, methods and principles of teaching will be abandoned. Educational resources will increasingly be oriented towards applied use and universal human values devoid of traditional meanings of a nation-state. Teaching and learning will not base solely on remembering and reproduction of information and academic knowledge. Pedagogy will recover its positions, ceasing to be extremely technological and aimed at goals of the industrial age. A textbook will be replaced by educational contentmedia and theme-based instruction [58]. The University is dead - long live the University!

\section{References}

1. R. Barnett, Realizing the University in an Age of Supercomplexity. (Open University Press, London, 1999)

2. B. Readings, The University in Ruins (Harvard University Press, Cambridge, 1997)

3. Global Flow of Tertiary-Level Students, UNESCO (Feb, 2016)

4. M.E. McMahon, Higher Education 4 (1992)

5. M.V. Boguslavskii, The Main Tendencies of Didactics Developing: Education in Postindustrial Society, Specific of Educational Activity in Postindustrial Society (2010) [In Rus]

6. M.V. Boguslavskii, Innovative Technologies in Education: Subjectivity, Resource Potential, Technology, Innovative Factors of Education in Information-Oriented Society (2011) [In Rus]

7. The New Teacher Project (TNTP): Reimagining Teaching in a Blended Classroom, Working Paper (November 2014) [In Rus]

8. M. Sharples, A. Adams, R. Ferguson, M. Gaved, P. McAndrew, B. Rienties, M. Weller, and D. Whitelock, Open University Innovation Report 3, Innovating Pedagogy 2014 (The Open University, London, 2014)

9. E.V. Neborskii, Pedagogy, 5 (2015) [In Rus]

10. M.V. Boguslavskii, Education in

Postindustrial Society: Axiological, HistoricPedagogical, Theoretical and Applied Aspects, Value Transformation of Education in Postindustrial Society (2012) [In Rus]

11. K. Robinson, and L. Aronica, Creative Schools: The Grassroots Revolution That's Transforming Education (Viking, New York, 2015)

12. H. Ortega-y-Gasset, Mission of the University (Princeton University Press, New York, 1944)

13. J.H. Newman, The Idea of a University (Aeterna Press, London, 2015)

14. E.V. Strogetskaya, Questions of Education 4 (2009) [In Rus]
15. J. Habermas, J.R. Blazek, New German Critique, 41 (1987)

A. Toffler, The Third Wave (Bantam, New York, 1984)

16. Advancing Knowledge and the Knowledge Economy. National Academies 21st and Constitution Ave (Washington, DC, Jan 2005)

17. M. Polanyi, The Tacit Dimension (University of Chicago Press, Chicago, 1966)

18. E.V. Neborskii, Science of Science, 4 (2015) [In Rus]

19. Y. Moulier-Boutang, Cognitive Capitalism (Polity Press, Malden, 2012)

20. J. Enders, Higher Education, 3 (2004)

21. M. McLuhan, The Gutenberg Galaxy (University of Toronto Press, Toronto, 2011)

22. I.A. Tagunova, The Developing of Supranational Education in the Context of the World Educational Space (Institute of Theory and History of Pedagogy, Moscow, 2007) [In Rus]

23. R. Robertson, Globalization: Social Theory and Global Culture (SAGE, London, 1992)

24. E.V. Neborskii, Problems of Modern Education, 3 (2015) [In Rus]

A. Sogomonov, Reserve Stock 5 (2006) [In Rus]

25. D.V. Rusanov, Globalization as a Trigger of Developing of Modern Higher Education: sociological aspect (Tambov State University, Tambov, 2009) [In Rus]

26. M.V. Boguslavskii, and E.V. Neborskii, Science of Science, 3 (2015) [In Rus]

27. G.G. Bubnov, N.G. Malyshev, E.V. Plyzhnik, and V.I. Soldatkin, Cloud of Science, 1 (2013) [In Rus] 28. L.A. Zelenov, A.A. Vladimirov, E.I. Stepanov, Modern Globalization. Conditions and Perspectives (Lenand, Moscow, 2010) [in Rus.]

29. Sh. Slaughter, Academic Capitalism and the New Economy: Markets, State and Higher Education (The John Hopkins University Press, Baltimore, 2009) 30. N. Chomskii, Scepsis, Assaulting SolidarityPrivatizing Education (May, 2000)

31. M. Burawoy, American Sociology Review, 70 (Feb, 2005)

32. J. Habermas, J.R. Blazek, New German Critique, 41 (1987)

33. B. Readings, The University in Ruins (Harvard University Press, Cambridge, 1997)

34. S.N. Zykova, Proceedings of Tomsk State University, 269 (2008) [In Rus]

35. M.M. Bakhtin, Marxizm and Language Philosophy (Labirint, Moscow, 2000) [In Rus]

36. G. Yudin, 3 (2011) [In Rus]

37. E.V. Neborskii, Pedagogy, 5 (2015) [In Rus]

38. J. Ritzen, $A$ Chance for European Universities: Or: Avoiding the Looming University Crisis in Europe (Amsterdam University Press, Amsterdam, 2011)

39. O.Kh. Miroshnikova, World of Science, 3 (2015) [In Rus]

40. Yu.A. Sazonova, Psychology Sociology and Pedagogy, 9 (2014) [In Rus] 
41. K. Jaspers, The Idea of the University (P. Owen, 1965)

42. N.V. Osipova, Modern University as a Social Institute (Moscow State University, Moscow, 2004) [In Rus]

43. J. Hennessy, Virtually It's our Best Shot (October, 2012)

44. S. Beckle, The Pie News, HE alliance to pilot MOOC credit transfer system (Jan 25, 2016)

45. S.K. Fedin, Vestnik MGLU, Forming of the University of Shanghai Cooperation Organization as a Factor of Humanities Cooperation of State-Partners of SCO (2011) [In Rus]

46. E.S. Belykova, Vestnik MGLU, Cooperation of State-Partners of SCO in Higher Education: SCO University as a Successful Model of Partnership (2013) [In Rus]

47. N.A. Yemikh, European Social Science Journal, 38 (2013)

48. M.V. Boguslavskii, E.V. Neborsky, Humanities Socio-Economical and Social Sciences, 9 (2014) [In Rus]C. Kerr, The Uses of the University (Harvard University Press, 2001)

49. H. Lefkowitz Horowitz, Campus Life: Undergraduate Cultures from the End of the Eighteenth Century to the Present (The University of Chicago Press, Chicago, 1988)
50. J. Knight, International Education Hubs: Student, Talent, Knowledge Models (Springer Publishers, Berlin, 2014)

A. Bozkurt, E. Akgun-Ozbek, S. Onrat-Yilmazer, E. Erdogdu, H. Ucar, E. Guler, S. Sezgin, A. Karadeniz, N. Sen, N. Goksel-Canbek, G.D. Dincer, S. Ari, and C.H. Aydin, International Review of Research in Open and Distributed Learning, 16 (2015)

B. Sanchez, Intel L. S. Blog, The use of technological resources for education: a new professional competency for teachers (2013)

51. L. Breslow, D.E. Pritchard, J. DeBoer, G.S. Stump, A.D. Ho, and D.T. Seaton, RPA Journal (June 14, 2013)

52. F. Paraskeva, S. Mysirlaki, and A. Papgianni, Computers and Education, 54 (2010)

53. E.V. Neborskii, Science of Science, 2 (2015) [In Rus] 